\title{
Tunnekausatiivilauseen argumenttirakenne I
}

\author{
NP aiheuttajana
}

SAARA HuHMARNIEMI

\section{Johdanto}

Tunnekausatiivilauseet luokitellaan usein omaksi lausetyypikseen, johon kuuluu tunnetta tai tuntemusta kuvaava verbi (tunnekausatiivi) ja partitiivisijainen kokija kuten lauseissa 1a-b (Hakulinen \& Karlsson 1979). ${ }^{1}$ Lisäksi tunnekausatiivilauseet voivat sisältää nominatiivimuotoisen ärsykkeen, jota kutsun tässä aiheuttajaksi (esim. 2a-b). Tunnekausatiivilause voi esiintyä ilman kokijaa, jolloin lause tulkitaan nollapersoonaiseksi (esim. 3a-b). (VISK $\$ 316,467,503,905$.)

(1) (VISK $\$ 905)$

a. Mua kaduttaa, nolottaa ja itkettää.

b. Selkää kutittaa.

(2) (VISK \$ 905)

a. Minua alkaa hiljalleen ottaa päähän tämä paikallaan istuminen.

b. Eräs asia harmittaa.

(3) (VISK \$ 905)

a. Pelottavatko lisäsairaudet? Suututtaako loputon omahoito?

b. Keljuttaa niin peijakkaasti, että tekisi mieli särkeä koko radio.

Tunnekausatiivilauseen aiheuttaja- ja kokija-argumenttien asema syntaktisessa rakenteessa on tällä hetkellä avoin kysymys, ja rakenteen on arvioitu jopa olevan muutoksessa (Siiroinen 2005). Tunnekausatiivilauseille on ehdotettu kirjallisuu-

1. Olen kiitollinen Anne Vainikalle arvokkaista kommenteista käsikirjoituksen aiempaan versioon. Kiitokset myös Kielitieteen päivien 2018 yleisölle sekä nimettömille arvioijille kommenteista. Tätä tutkimusta on rahoittanut Koneen Säätiö. 
dessa kahdentyyppisiä rakenteita liittyen kokijan ja aiheuttajan keskinäiseen järjestykseen. Iso suomen kielioppi analysoi nominatiivimuotoisen aiheuttajan subjektiksi ja partitiivimuotoisen kokijan objektiksi (VISK $\$ 467$ ). Siiroinen (2005) puolestaan analysoi tunnekausatiivilauseen konstruktioksi, jossa kokija esiintyy ennen verbiä ja aiheuttaja verbin jälkeen (esim 4). Sulkeet merkitsevät optionaalisuutta. Kokija on sijoitettu ennen verbiä, kun taas aiheuttaja on verbin jäljessä.

(4) (par-NPexp) V (nom-NPstim)

Siron (1996 [1978]) ehdottamassa konstituenttirakenteessa kokija sijaitsee niin ikään ennen aiheuttajaa. Generatiivisen syntaksin malleissa aiheuttaja sijoitetaan toisinaan hierarkkisessa argumenttirakenteessa ylemmäs kuin kokija (esim. Pylkkänen 2002), toisinaan taas kokijan alapuolelle (mm. Nelson 2000; Kupula 2010).

Tässä artikkelissa osoitan, että valtaosa kieliopillisista testeistä tukee analyysiä, jonka mukaan nominatiivimuotoinen aiheuttaja sijaitsee tunnekausatiivilauseen argumenttirakenteessa ylempänä kuin partitiivimuotoinen kokija. Tämä argumenttirakenne sallii runsaasti sanajärjestyksen vaihtelua, jonka oletan olevan sidoksissa puhetilanteeseen ja argumenttien ominaisuuksiin.

Argumenttien keskinäisten suhteiden lisäksi tarkastelen tunnekausatiivilauseen ja perussubjektillisen lauseen syntaktisia eroja. Jotkin tunnekausatiivit, kuten jännittää, voivat esiintyä myös perussubjektillisessa lauseessa siihen tapaan kuin esimerkeissä 5a-b (VISK $\$ 467$ ). Toisaalta sellaisilla verbeillä kuin harmittaa ja kaduttaa näyttää olevan ainoastaan tunnekausatiiveille tyypillinen argumenttirakenne.

(5) (Vilkuna 2002: 120)

a. Minä jännitän tilaisuutta.

b. Minua jännittää tilaisuus.

Vertailen tunnekausatiivilausetta transitiivilauseeseen ja ehdotan, että keskeiset kieliopilliset erot voidaan analysoida olettamalla, että perussubjekti on verbilausekkeen ulkoinen argumentti, kun taas tunnekausatiivilauseen aiheuttaja on peräisin verbilausekkeen sisältä (Pylkkänen 1999a, 1999b; Nelson 2003). Tämän oletuksen perusteella esittelen tunnekausatiivilauseelle syntaktisen analyysin. Täydennän kieliopillista tarkastelua Kielipankin Suomi24-korpusaineistosta tekemilläni havainnoilla etenkin sanajärjestyksen osalta. ${ }^{2}$

Tämä artikkeli on ensimmäinen osa kahden artikkelin sarjaa, jonka aiheena on tunnekausatiivilauseen argumenttirakenne. Tässä artikkelissa keskityn lauseisiin, joissa aiheuttaja on NP eli substantiivilauseke (ks. VISK $\$ 442$, määritelmät s.v. NP). Artikkelisarjan toinen osa (Huhmarniemi tulossa 2019) käsittelee lausemaisia aiheuttajia: A-infinitiiviä (esim. 6a-b), kun-lausetta (esim. 7a) ja että-lausetta (esim. 7b).

2. Esimerkkien yhteyteen on merkitty lähdeviite, joka ilmoittaa, mistä esimerkki on peräisin. Merkitsemättömät esimerkit olen keksinyt itse. 
(6) (VISK $₫ 503)$

a. Margaretaa pelotti mennä ulos, vaikka hänellä oli santarmi seuranaan.

b. Kansalaisia varmasti kiinnostaisi nähdä Lipponen ja Aho vastakkain.

(7) a. Tässäpä minua huvittaa, että uudistus lanseerattiin taas keskeneräisenä - (Internet 1)

b. Ihmetyttää, kun kaikki on käynyt niin nopeasti tässä kesän aikana. (Internet 2)

Luvussa 2 esitän kausatiivimorfeemiin ja tunnekausatiiviverbin muodostamiseen liittyvät perusoletukset nojautuen aiempaan tutkimukseen. Käytän tunnekausatiivilauseen syntaktiseen analyysiin generatiivisen tutkimusparadigman perustyökaluja, jotka esittelen luvussa 3 . Luvussa 4 vertailen tunnekausatiivilauseen ja transitiivilauseen rakennetta ja käyn läpi kieliopillisia testejä, jotka tukevat oletusta, että tunnekausatiivilauseesta puuttuu ulkoinen subjekti ja aiheuttaja-subjekti sijaitsee verbilausekkeen sisällä. Luvussa 5 tarkastelen tunnekausatiivilauseen argumenttien järjestystä rakenteessa. Tavoitteeni on osoittaa, että kun aiheuttaja on substantiivilauseke, se sijaitsee tyypillisesti ylemmässä positiossa kuin kokija. Käsittelen kieliopillista aineistoa kongruenssista, anaforien sidonnasta ja sanajärjestyksestä. Luvussa 6 esitän päätelmät.

\section{Tunnekausatiivin muodostamiseen liittyvät perusoletukset}

Tunnekausatiivi on produktiivinen verbityyppi, joka voidaan muodostaa monenlaisista kantasanoista. Useimpiin tunnekausatiiveihin liittyy kausatiivimorfeemi ${ }^{3}$, ja johtimena on tavallisesti - $t t A-,-U t t A$ - tai $-t U t t A$ - (VISK $\$ 316)$. Vaikka tunnekausatiivit sisältävät yleensä kausatiivimorfeemin, ne eroavat syntaktisesti ja semanttisesti tyypillisistä kausatiivisista ilmaisuista. Tyypillinen kausatiivinen ilmaisu kuvaa subjektin aiheuttamaa tapahtumaa tai tilan muutosta. Esimerkiksi oven avaamisesta seuraa, että ovi on auki, joten lause 8a sisältää ristiriidan. ${ }^{4}$ Partitiiviobjekti mahdollistaa kuitenkin tuloksettoman tulkinnan, mitä havainnollistaa esimerkki 8b. Vastaavasti lauseet $8 \mathrm{c}-\mathrm{d}$ osoittavat, että kausatiivimorfeemi ei vielä yksin edellytä muutosta tilassa (esim. Kupula 2010). Kausatiivimorfeemin tulkintaan tilan muutoksena vaikuttavat siis myös muut tekijät, kuten lauseen aspekti.

(8) a. \#Pekka avasi oven, mutta ovi ei avautunut. (ristiriita)

b. Pekka avasi ovea, mutta ovi ei avautunut.

c. \#Pekka kasvatti kukan, mutta kukka ei kasvanut. (ristiriita)

d. Pekka kasvatti kukkaa, mutta kukka ei kasvanut.

3. Rakenteeltaan samantyyppisiä verbejä ovat esimerkiksi ahdistaa ja särkeä (VISK \$ 316).

4. Esimerkeissä merkintä * tarkoittaa epäkieliopillista lausetta ja merkintä ? lausetta, joka ei ole hyväksyttävä muttei myöskään selvästi epäkieliopillinen. Kysymysmerkillä merkityn lauseen ongelma voi olla semanttinen tai syntaktinen; merkintä ei ota tähän kantaa. Merkintä \# tarkoittaa semanttisesti tai pragmaattisesti ongelmallista lausetta. Merkintöjä käytetään ilmaisujen vertailun apukeinona. Hyväksyttäviä lauseita ei ole merkitty erikseen. 
Tunnekausatiiveilla ilmaistaan tyypillisesti tilan muutoksen sijaan tunnetiloja (VISK $\$ 467)$. Nämä tunnetilat ovat luonteeltaan statiivisia ja ateelisiä; ne eivät sisällä muutosta, eikä tilassa ole päätepistettä tai tulosta (VISK $\$ 1501$ ). Kausatiivimorfeemin avulla on mahdollista muodostaa tilaa ilmaisevista predikaateista toisia tilaa ilmaisevia predikaatteja kuten verbistä surra kausatiivimuoto surettaa lauseissa 9a-b. Toisaalta tunnekausatiivia ei voida käyttää esimerkiksi progressiivisen MA-infinitiivin kanssa (esim. 10a), joka ilmaisee käynnissä olevaa, luonteeltaan väliaikaista tilannetta ja sisältää tietoisen subjektin. Sama pitää paikkaansa muiden pysyviä tiloja ilmaisevien verbien suhteen (esim. 1ob), kun taas esimerkiksi verbeistä surra ja sääliä voidaan käyttää MA-infinitiivimuotoa (esim. 10c) (VISK $₫ 1504,1519)$.

(9) (Pylkkänen 1999b)

a. Matti suree uutisia.

b. Uutiset surettavat Mattia.

(10) a. ${ }^{*}$ Kaisa on inho-tta-massa / sääli-ttä-mässä Matti-a. (Pylkkänen 1999: 7)

b. ${ }^{\star}$ Hän on rakasta-massa minua. (VISK $\$ 1519$ )

c. Kaisa on sure-massa / sääli-mässä Matti-a.

Tunnetilan ilmaisemisen lisäksi tunnekausatiivin kausatiivimorfeemi liittyy tilan tai tunnetilan aiheuttamiseen (Pörn 2001; Pylkkänen 2002; Cathcart \& Vainikka 2019). Rakenteeseen sisältyy usein myös nominatiivimuotoinen argumentti, joka voidaan tulkita tilan aiheuttajaksi (esim. Pörn 2001; Kupula 2010). Cathcart ja Vainikka (2019) esittävät, että vasta aiheuttajan liittäminen rakenteeseen tekee rakenteesta kausatiivisen. Toisaalta esimerkiksi Pylkkäsen (2002) mallissa kausatiivimorfeemiin liittyy tapahtuma, joka toimii tilan aiheuttajana (ks. myös Nelson 2000). ${ }^{5}$

Generatiivisessa kieliopintutkimuksessa leksikon elementit voidaan jakaa kahteen luokkaan: leksikaaliset kategoriat, kuten nominit, verbit tai adpositiot, ja funktionaaliset kategoriat, joihin kuuluvat artikkelit, aikamuoto ja monet sidonnaiset morfeemit. Molemmat kategoriat voivat toimia lausekkeiden pääsanoina syntaktisessa rakennepuussa. Generatiivisen syntaksintutkimuksen malleissa suomen kausatiivisia ilmauksia kuvataan usein rakennepuulla, joka sisältää erillisen funktionaalisen pääsanan kausatiivimorfeemia varten (Pylkkänen 2002; Kupula 2010). Toinen vaihtoehto on sijoittaa kausatiivimorfeemi rakenteessa johonkin muuhun sopivaan pääsanaan (Nelson 2000). Tämä artikkeli perustuu oletukseen, että tunnekausatiivilauseen perusrakenne sisältää funktionaalisen Caus-pääsanan.

Tunnekausatiivin kantasana voi olla transitiivinen (esim. 11a) tai intransitiivinen verbi (esim. 11b). Myös intransitiivisesta kannasta muodostettu tunnekausatiivi voi ot-

5. Pylkkäsen ehdottaman mallin ongelma on, että joillain tunnekausatiiveilla ei näytä olevan aiheuttajaa lainkaan (i). Aiheuttajan lisääminen on silti mahdollista (ii).

(i) ?Lapsia janottaa, mutta en tiedä mikä.

(ii) Juokseminen janottaa lapsia 
taa kaksi argumenttia, aiheuttajan ja kokijan, kuten lauseissa 12a-b. Kantasana voi olla myös nomini kuten verbeillä harmittaa ja huvittaa, tai kantasana voi puuttua kokonaan kuten verbeiltä hauko(tu)ttaa, oksettaa ja viehättää (VISK \$316).

(11) (VISK $\$ 905)$

a. Heitä pelotti kylmyys. vrt. He pelkäsivät kylmyyttä.

b. Heitä väsytti. vrt. He väsyivät.

(12) (Suomi24)

a. Minua väsyttää kuumuus.

b. Häntä väsytti autolla ajo.

Hajautetun morfologian malli (distributed morphology) tarjoaa yhden vaihtoehdon tunnekausatiivin analyysiin (Halle \& Marantz 1993; Marantz 1997). Hajautetussa morfologiassa kielen sanat muodostetaan kategorianeutraaleista juurista. Esimerkiksi verbi syö-dä ja substantiivi syö-minen muodostetaan samasta juurimuodosta, johon liitetään kategorian tunnus syntaksisessa rakenteessa (kuviot 1a-b). Pääsana Caus tuo rakenteeseen kausatiivimorfeemin juuren (kanta) ja kategorian tunnuksen (kuvio 1c).

(a)

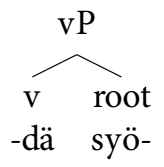

(b)



(c)

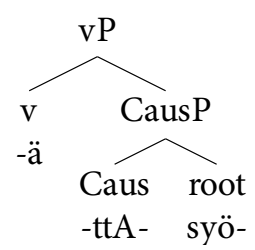

Kuvio 1.

Sanojen muodostaminen kategorianeutraalista juuresta hajautetun morfologian mallissa.

Hajautetun morfologian mallissa nominikantaiset tunnekausatiivit, kuten harmi-tta-a, ja verbikantaiset tunnekausatiivit, kuten pelo-tta- $a$, johdetaan siis morfosyntaktisesti kategorianeutraaleista juurista liittämällä juureen morfeemeja vastaavia pääsanoja. Oletan tässä Bakerin (1985) peiliperiaatteen (mirror principle) mukaisesti, että morfeemien lineaarinen järjestys sanan sisällä peilaa morfeemeja vastaavien pääsanojen hierarkkista järjestystä rakenteessa. ${ }^{6}$ Sidonnaisten morfeemien lineaarinen järjestys määräytyy siis hierarkkisen rakenteen perusteella.

Seuraan tässä artikkelissa hajautetun morfologian mukaista analyysiä, mutta vastaava argumenttirakenteen tarkastelu voidaan tehdä myös ilman oletuksia tunnekausatiivin morfosyntaksista. Tunnekausatiivilauseen argumenttirakennetta tarkastelen luvuissa 4 ja 5 .

6. Tässä artikkelissa siis oletetaan, että Caus-pääsana tuo rakenteeseen kausatiivimorfeemin. Tunnekausatiiveihin kuuluu myös verbejä, kuten ahdistaa ja särkeä, joilla ei ole kausatiivimorfeemia. Näissä tapauksissa oletetaan, että rakenne sisältää Caus-pääsanan, mutta kausatiivimorfeemi jää lausumatta. 


\section{Perusoletukset finiittilauseen muodostamisesta generatiivisessa paradigmassa}

Esittelen tässä luvussa lyhyesti tunnekausatiivilauseen syntaktiseen analyysiin tarvittavat generatiivisen tutkimusparadigman (Chomsky 1995) oletukset: transitiivilauseen argumenttirakenteen, rakenteessa tapahtuvat siirtymät ja refleksiivisten anaforien sidontaehdon A.

\subsection{Transitiivilauseen argumenttirakenne}

Kuvio 2 havainnollistaa yksinkertaisen transitiivilauseen argumenttirakennetta, joka vastaa lauseen temaattista rakennetta. Objekti asettuu verbin komplementtiin. Artikkelini perustuu hypoteesiin, että transitiivi- ja epäergatiivilauseilla on verbilausekkeen ulkopuolinen, niin kutsuttu ulkoinen subjekti; tämä subjekti sijoitetaan funktionaalisen Voice-projektion määritteeseen (engl. specifier; ks. Kratzer 1996). Voice-pääsana, joka sisältää verbin pääluokan (aktiivi/passiivi), kiinnittää ulkoisen argumentin, kuten agentin, temaattisen roolin.

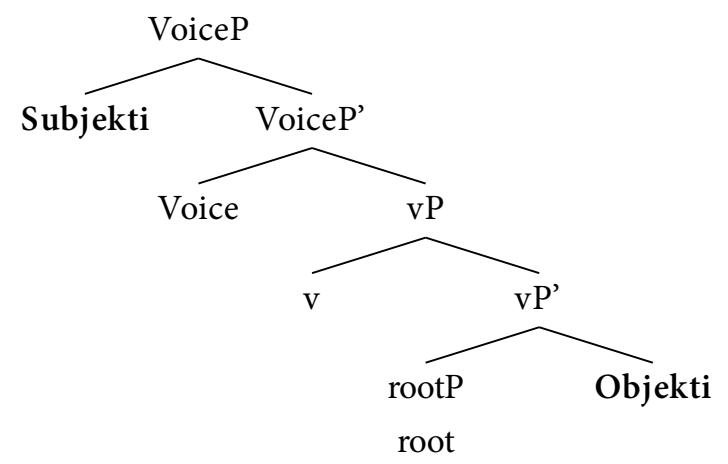

Kuvio 2.

Yksinkertaisen transitiivilauseen argumenttirakenne.

Tämän rakenteen perusteella määräytyy suomessa muun muassa refleksiivisten anaforien tulkinta. Rakenne ei vielä sisällä lauseen teemapaikkaa; sen esittelen seuraavassa alaluvussa.

\subsection{Siirtymät lauseen teemapaikkaan}

Suomessa finiittilauseen teemapaikka sijaitsee finiittiverbin edellä (VISK \$ 1372). Esimerkissä 13a teemapaikassa on lauseen subjekti ja esimerkissä 13b objekti.

(13) a. Pekka lainasi tuon kirjan.

b. Tuon kirjan lainasi Pekka. 
Syntaktisessa rakenteessa tätä sanajärjestysvaihtelua kuvataan siirtymän avulla, kuten kuviosta 3 ilmenee. Suomessa teemapaikan oletetaan sijaitsevan aikamuotoa ilmaisevan T(ense)-projektion määritteessä, joka sijoitetaan VoiceP:n yläpuolelle.7 Lisäksi finiittiverbi siirtyy T-pääsanaan, jossa se saa aikamuodon ja subjektin kongruenssipiirteet.
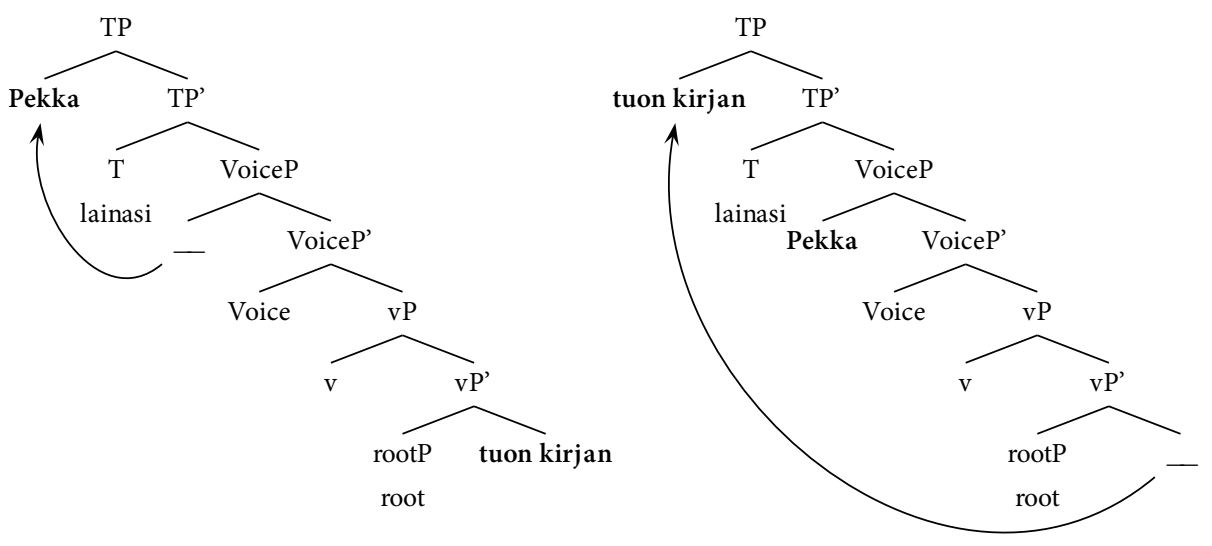

Kuvio 3.

Subjektin ja objektin siirtymät lauseen teemapaikkaan.

Suomessa transitiivilauseen subjekti on oletusarvoinen teema (VISK $₫ 1372$ ). Subjektin ensisijaisuus teemapaikassa voidaan analysoida olettamalla siirtymän noudattavan läheisyysperiaatetta (attract closest, Chomsky 1995), jonka mukaan siirrettäväksi valitaan aina lähin sopiva elementti. Läheisyysperiaatteen mukaisesti subjekti siirtyy teemapaikkaan oletusarvoisesti, ellei puhetilanne vaadi jonkin muun elementin käyttöä teemapaikassa (Huhmarniemi 2019). Läheisyysperiaatteen lisäksi puhetilanne ja lauseen informaatiorakenteeseen liittyvät tekijät vaikuttavat siihen, mikä elementti teemapaikkaan valitaan. Hyödynnän siirtymän läheisyysperiaatetta myöhemmin tunnekausatiivilauseen sanajärjestyksen tarkastelun yhteydessä alaluvussa 5.3.

Tässä artikkelissa ei käsitellä rakenteen yksityiskohtia tarkemmin; suomen kielen peruslauseen rakennetta on minimalistisessa viitekehyksessä esitellyt esimerkiksi Huhmarniemi (2012).

\subsection{Refleksiivisen anaforan sidonta}

Refleksiivisen anaforan sidonta muodostetaan suomessa lähtökohtaisesti argumenttirakenteen perusteella. Suomen refleksiivinen anafora noudattaa sidontaehtoa A (condition A, Chomsky 1981), jonka mukaan refleksiiviaines vaatii aina paikallisen

7. Vainikka (1989) esitti ensimmäisenä analyysin suomen finiittilauseen rakenteesta, jossa teemapaikka on verbilausekkeen ulkopuolella olevan funktionaalisen projektion määritteessä. Esitetty rakenne on yksi variaatio tästä perusrakenteesta. Esimerkiksi Holmberg ja Nikanne (2002) olettavat lisäksi projektion Fin(iteness) T:n yläpuolelle, mutta tässä artikkelissa riittää oletus T-projektiosta. 
k-komentavan korrelaatin. K-komennus (c-command, constituent-command) määritellään syntaktiseksi relaatioksi: rakenteen solmu X k-komentaa solmua Y, jos Y on X:n sisar tai Y on X:n sisaren jälkeläinen. ${ }^{8}$

Refleksiivisellä anaforalla tarkoitetaan tässä Ison suomen kieliopin mukaisia refleksiiviaineksia: refleksiivipronominia (itsensä), resiprookkipronominia (toisensa) ja refleksiivistä possessiivisuffiksia -nsA (VISK $\$ 1445$ ). Korrelaatin paikallisuus tarkoittaa, että refleksiivisen anaforan sidonta ei voi ylittää finiittilauseen rajaa.

Sidontaehdosta A seuraa, että refleksiivisen anaforan korrelaatin on argumenttirakenteessa sijaittava ylemmässä positiossa kuin itse anaforan. Esimerkiksi transitiivilauseen subjekti voi sitoa objektipositiossa olevaa refleksiivistä anaforaa (esim. 14a), mutta päinvastainen ei ole mahdollista (esim. 14b). Suomessa myös 3. persoonan possessiivisuffiksi on refleksiivinen anafora ja noudattaa sidontaehtoa A kuten lauseissa 15a-b (Vainikka 1989: 193-195; Trosterud 1993).

(14) a. Pekka näki itsensä.

b. ${ }^{\star}$ Itse(-nsä $\left.{ }_{\mathrm{i}}\right)$ näki Pekan ${ }_{\mathrm{i}}$.

(15) a. Pekka ${ }_{i}$ näki poikansa.

b. ${ }^{\star}$ Poikansa $_{\mathrm{i}}$ näki Pekan ${ }_{\mathrm{i}}$.

On kuitenkin huomattava, että puhekielessä, jolla tarkoitan myös normittamatonta kirjoitettua kieltä, refleksiivinen possessiivisuffiksi hakee korrelaatteja myös kontekstista kuten esimerkissä 16 (ks. esim. Huhmarniemi \& Brattico 2015).

(16) Äitinsä hakee kaupasta lahjan ja - - (Internet 3)

Argumenttirakenteen perusteella muodostetut sidontasuhteet ovat yleensä pysyviä, eivätkä ne muutu, kun elementit siirtyvät rakenteessa. Esimerkiksi lauseessa 17a subjekti sitoo refleksiivistä anaforaa itselleen, joka sijaitsee rakenteessa subjektin alapuolella. Lauseessa $17 \mathrm{~b}$ adverbiaali on siirtynyt teemapaikkaan, mutta anaforien sidontasuhde säilyy. Rakenteessa alempana oleva elementti ei voi sitoa subjektina toimivaa refleksiivistä anaforaa, mikä ilmenee esimerkistä 17 c. Sanajärjestykseen liittyvät siirtymät eivät siis suomen kielessä luo uusia sidontasuhteita. Esimerkissä 17 d adverbiaali Pekalle on siirtynyt teemapaikkaan refleksiivisen anaforan edelle, mutta se ei edelleenkään voi toimia korrelaattina anaforalle.

8. Määritelmän mukaan siis esimerkissä (i) solmu B k-komentaa solmuja C, D, E, F ja G. Toisaalta esimerkiksi solmu $\mathrm{H}$ k-komentaa solmua I, mutta ei muita rakenteen solmuja.

(i)

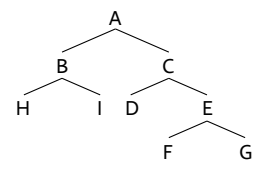


(17) a. Pekka antoi sen kirjan itselleen ${ }_{\mathrm{i}}$.

b. Itselleen ${ }_{i}$ antoi Pekka sen kirjan.

c. ${ }^{*}$ Itsensä antoi sen kirjan Pekalle ${ }_{i}$.

d. ${ }^{\star}$ Pekalle $_{\mathrm{i}}$ antoi itsensä̈ sen kirjan.

Anaforien sidontaehdon A avulla on siis mahdollista selvittää, mikä lauseen elementtien hierarkkinen asema on ollut rakenteessa ennen siirtymiä. Seuraavaksi siirryn tarkastelemaan tunnekausatiivilauseen rakennetta. Luvussa 4 esittelen tunnekausatiivilauseen ja transitiivilauseen kieliopillisia eroja; luvussa 5 tarkastelen aiheuttaja- ja kokija-argumenttien suhteellista asemaa lauseessa.

\section{Tunnekausatiivilauseen ja transitiivilauseen vertailua}

Tässä luvussa käyn läpi kieliopillisia testejä, joiden perusteella tunnekausatiivilauseen nominatiivimuotoinen aiheuttaja poikkeaa syntaktisesti transitiivilauseen ja epäergatiivilauseen subjekteista. Vertailen temaattisia rooleja, objektin sijavaihtelua, passiivin ja imperatiivin muodostamista, nominaalistuksia ja partisiippien muodostamista. Pylkkänen (1999a) on esittänyt, että toisin kuin transitiivilauseilla tunnekausatiivilauseilla ei ole ulkoista subjektia. Sen sijaan tunnekausatiivilauseen subjekti sijaitsee alempana rakenteessa, verbilausekkeen sisällä (ks. myös Nelson 2003; Alexiadou, Anagnostopoulou \& Schäfer 2006; Harley 2013; Kupula 2010; Cathcart \& Vainikka 2019). Pylkkäsen (1999a) mukaan tunnekausatiiveilta puuttuu pääsana, joka tuo rakenteeseen ulkoisen argumentin. Olen tässä Pylkkäsen kanssa samalla kannalla.

Keskeinen perussubjektillisen ja tunnekausatiivilauseen ero koskee argumenttien temaattisia rooleja: transitiivilauseen subjekti voidaan tulkita agentiksi esimerkissä 18a, kun taas tunnekausatiivilauseen subjekti ei ole agentiivinen (esim. 18b). Myös objektin temaattinen rooli tyypillisesti vaihtelee; esimerkiksi lauseessa 18 a objekti on teema ja lauseessa $18 \mathrm{~b}$ taas kokija. Lause $18 \mathrm{c}$ on subjektin agentiivisuuden kannalta kaksitulkintainen.

(18) a. Minä (agentti) autan Merjaa (teema).

b. Minä (aiheuttaja) sälitin Merjaa (kokija)

c. Minä nauratin Merjaa.

Pylkkänen (1999a) esittää, että statiiviset verbit, kuten säälittää, kiinnittävät verbilausekkeen sisäiset kokijan ja teeman temaattiset roolit (ks. myös Nelson 2000, 2003). Ulkoisen subjektin temaattisen roolin puuttuminen viittaa siihen, että tämän roolin kiinnittävä pääsana puuttuu rakenteesta (Kratzer 1996). Tätä tukee myös havainto, että monet agentiivisiin subjekteihin liittyvät välineen adverbiaalit ovat tunnekausatiiveilla mahdottomia (esim. 19a-b).

(19) a. Minä nukutin lasta laulamalla.

b. *?Minä säälitin Merjaa laulamalla. 
Toisaalta tunnekausatiivilausetta ei voida käyttää infiniittisessä komplementissa, joka vaatii agentiivisen aiheuttajan (esim. 20a-b). Ero on selvä verrattuna transitiivilauseisiin (esim. 20c).

(20) a. ?Minä yritän ihmetyttää sinua.

b. *?Hän haluaa säälittää sinua.

c. Minä yritän auttaa sinua.

Toinen keskeinen ero tunnekausatiivilauseen ja transitiivilauseen välillä koskee objektin sijavaihtelua. Tunnekausatiivilauseen objekti on aina partitiivissa, kun taas osa transitiiviverbeistä voi saada totaaliobjektin (esim. 21). Burzion (1986) yleistyksen mukaan verbi voi kiinnittää ulkoisen argumentin temaattisen roolin, jos ja vain jos se voi ottaa akkusatiivisijaisen objektiargumentin. Suomen tunnekausatiivilauseessa ei ole totaaliobjektia, joka voitaisiin tulkita akkusatiivisijaiseksi objektiksi. Tämä tukee näkemystä, että tunnekausatiiveilta puuttuu ulkoinen subjekti. Tunnekausatiivi ilmaisee rajaamatonta tilaa, joten kokijaobjektin partitiivisija on myös semanttisesti perusteltu.

(21) Minä suututin Merjan/Merjaa.

Kolmas ero transitiivilausen ja tunnekausatiivilauseen välillä on se, että tavallisen transitiivilauseen voi muuttaa passiiviin (esim. 22a), mutta tunnekausatiivilausetta ei voi (esim. 22b-c) (VISK \$ 905).

(22) a. Merjaa suututettiin.

b. ${ }^{\star}$ Merjaa harmitettiin.

c. ${ }^{*}$ Merjaa säälitettiin.

Ison suomen kieliopin (VISK $\$ 1321$ ) mukaan passiivi muodostetaan verbeistä, jotka voivat saada ihmistarkoitteisen perussubjektin, eikä tunnekausatiivilauseen subjektia pidetä perussubjektina. Manninen ja Nelson (2004) esittävät, että suomen passiivin morfologia ja passiivin muodostamiseen liittyvät syntaktiset operaatiot ovat peräisin ylimmästä, verbilausekkeen ulkoisesta v-projektiosta. Passiivi muodostetaan poistamalla tästä projektiosta ihmistarkoitteinen argumentti. ${ }^{9}$ Manninen ja Nelson olettavat Pylkkästä (1999a) seuraten, että tunnekausatiivin molemmat argumentit sijaitsevat verbilausekkeen sisällä, ja perustelevat, että passiivin muodostaminen on tästä syystä mahdotonta (Manninen \& Nelson 2004: 231-232). Tämän artikkelin mallissa ylintä v-projektiota vastaa Voice-projektio, ja sen puuttuminen siis aiheuttaisi ongelman passiivin muodostamisessa.

9. Manninen ja Nelson (2004) huomioivat mallissaan, että ulkoisen subjektin tai sen position puuttuminen ei aina johda ongelmiin passiivin muodostamisessa. Suomessa esimerkiksi epäakkusatiivilauseella on passiivirakenne, vaikka ulkoinen subjekti puuttuu. 
Samantyyppinen rajoitus voidaan havaita imperatiivilauseissa. Imperatiivin tulkinta vaatii (usein implisiittisen) tekijän, joka toimii ulkoisena subjektina. Osalla tunnekausatiiveista imperatiivimuoto näyttää olevan käytössä (esim. 23), mutta suurimmalle osalle ei Suomi24-korpusaineistosta löytynyt ainuttakaan esiintymää.

\section{(23) Älä ällötä niin paljon. (Suomi24)}

Neljäs argumentti sen puolesta, että tunnekausatiivilauseen subjekti sijaitsee eri positiossa kuin transitiivilauseen subjekti, liittyy nominaalistuksiin. Transitiivilauseen nominaalistus voi säilyttää sekä objektin että ulkoisen subjektin, kuten esimerkeistä $24 \mathrm{a}-\mathrm{b}$ ilmenee. Sen sijaan tunnekausatiivilauseen nominaalistus on rajoitetumpaa (esim. 25a-b). Puhekielestä voidaan kuitenkin löytää ilman argumentteja esiintyviä tunnekausatiivien nominaalistuksia (esim. 26a-b).

(24) a. Pekka suututti tuomarin - - eikä [tuomarin suututtaminen] ollut kovin järkevää. (Kirstilä 2002)

b. äidin kahvin juominen (VISK \$ 579)

(25) a. Pelaaja harmitti tuomaria - - eikä *[tuomarin harmittaminen] ollut kovin järkevää.

b. ${ }^{\star}$ Vanhemman tulisi kunnioittaa [lapsen nolottamista].

(26) a. - - hyvässä seurassa harmittaminen loppui - - (Internet 4)

b. Tuosta aamulla kaduttamisesta tuli tuoreeseen mieleeni, - - (Internet 5)

Tunnekausatiivista voidaan siis johtaa verbivastineellinen substantiivi, mutta sen argumenteilla ei ole vastineita substantiivilausekkeessa. Tämä havainto tukee analyysiä, jonka mukaan tunnekausatiivilauseen argumentit sijaitsevat eri positioissa kuin transitiivilauseen objekti ja ulkoinen subjekti. ${ }^{10}$

Viides esimerkki argumenttirakenteiden eroista koskee partisiippeja: ainoastaan ulkoinen subjekti voi esiintyä agenttirakenteessa (esim. 27a), aiheuttaja ei (esim. 27 b). Esimerkki osoittaa jälleen agentiivisen subjektin ja aiheuttajasubjektin välisen eron, joka voidaan liittää Voice-projektioon. Tunnekausatiivi ei ole vastaavalla tavalla epäkieliopillinen VA-partisiipissa, joka säilyttää objektiargumentin (esim. $28 \mathrm{a}-\mathrm{b})$.

(27) a. opiskelija suututti professorin - - [opiskelijan suututtama] professori

b. sää harmitti miestä - - *[sään harmittama] mies

10. On mahdollista löytää tapauksia, joissa aiheuttaja säilyisi nominaalistuksessa, kuten “Varsinkin jos onnettomuus tai vahinko ei johdu itsestä moisen vahingon harmittaminen ja siitä kiukustuminen ei ole ollenkaan ihmeellistä." (Internet 6.) Nämä tapaukset vaikuttavat harvinaisilta, eivätkä intuitioni mukaan ole kielenmukaisia. Käyttämästäni korpusaineistosta ei löytynyt vastaavia esimerkkejä. 
(28) a. Ainoa [[minua suututtava] asia] tässä on - - (Internet 7)

b. ?Toinen [[minua harmittava] seikka] ovat nuo - - (Internet 8)

Lisäksi Pylkkänen (2002: 89) toteaa esimerkkien 29a-b perusteella, että mikäli aiheuttaja on lauseessa implisiittinen, se tulkitaan tapahtumaksi. Tämä antaa tukea oletukselle, jonka mukaan implisiittinen aiheuttaja ei saa rakenteessa ulkoisen subjektin temaattista roolia.

(29) (Pylkkänen 2002: 89)

a. Minua naurattaa mutten tiedä mikä.

b. ${ }^{*}$ Minua naurattaa mutten tiedä kuka.

Tässä luvussa olen tarkastellut tunnekausatiivilauseen ja perussubjektillisen lauseen eroja. Eroavaisuudet viittaavat siihen, että toisin kuin transitiivilauseessa tunnekausatiivilauseessa ei ole ulkoista subjektia ja aiheuttaja-subjekti on sen sijaan peräisin verbilausekkeen sisältä (Pylkkänen 1999a, 2002; Nelson 2000, 2003; Kupula 2010). Ulkoisen subjektin puuttuminen on mahdollista analysoida olettamalla, että tunnekausatiivilauseilta puuttuu Voice-pääsana, jonka määritteessä ulkoinen subjekti sijaitsee.

\section{Tunnekausatiivilauseen argumenttirakenne}

Edellinen luku keskittyi vertailemaan transitiivilauseen ja tunnekausatiivilauseen rakenteellisia eroja paikantaen erot subjektiargumentin sijaintiin joko verbilausekkeen ulkopuolella (transitiivilause) tai sen sisäpuolella (tunnekausatiivilause). Tässä luvussa siirryn tarkastelemaan tunnekausatiivilauseen aiheuttajasubjektin tarkempaa sijaintia verbilausekkeen sisällä. Pyrin osoittamaan, että aiheuttajana toimiva substantiivilauseke sijoittuu tunnekausatiivilauseen argumenttirakenteessa ylemmäs kuin kokija. ${ }^{11}$ Ehdotettu rakenne on esitetty kuviossa 4 . Caus-pääsana sisältää kausatiivimorfeemin, ja aiheuttaja asettuu Caus-pääsanan määritteeksi. Oletan lisäksi, että rakenne sisältää Exp(eriencer)-pääsanan, jonka määritteeseen kokija sijoittuu. Tämän pääsanan tehtävänä on tuoda kokija-argumentti rakenteeseen ja kiinnittää kokijan temaattinen rooli. Tässä mallissa Exp-pääsanalle ei anneta muuta tehtävää.

Esittelen seuraavaksi kieliopillisia testejä, jotka tukevat kuvion 4 analyysiä tunnekausatiivilauseen argumenttirakenteeksi, kun aiheuttaja on NP. Keskeistä on jälleen vertailla tunnekausatiivilausetta transitiivilauseeseen. Seuraavissa alaluvuissa käyn läpi ominaisuuksia, jotka tukevat aiheuttajan sijoittamista rakenteessa kokijan yläpuolelle vastaavasti kuin transitiivilauseen subjekti sijaitsee argumenttirakenteessa

11. Tässä artikkelissa tarkastelen vain sellaisia NP:itä, jotka eivät sisällä lausemaista osaa. Esimerkiksi aiheuttajana toimivat NP:t, jotka sisältävät että-lauseen (Minua harmittaa [se, että en löydä sinua.]) jäävät tarkastelun ulkopuolelle. 
objektin yläpuolella. Tarkastelen kongruenssia alaluvussa 5.1 ja anaforien sidontaa alaluvussa 5.2. Sekä kongruenssi että anaforien sidonta määräytyvät argumenttirakenteen perusteella ja ovat siis riippumattomia tunnekausatiivin lopullisesta sanajärjestyksestä.

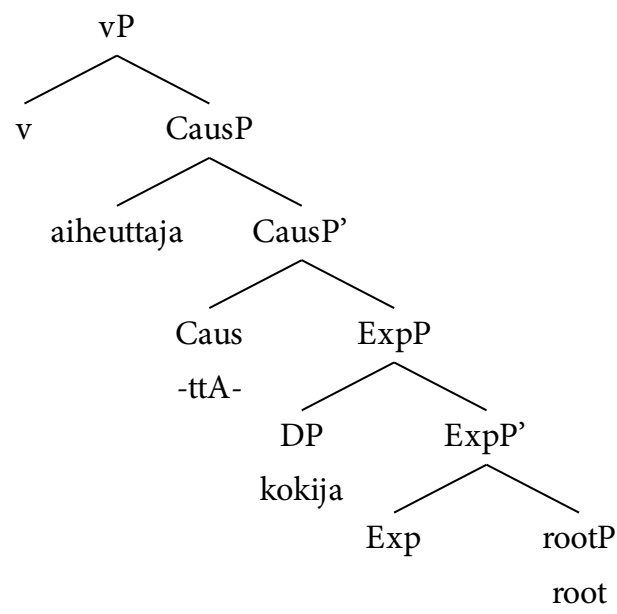

Kuvio 4.

Tunnekausatiivilauseen argumenttirakenne.

Tunnekausatiivilauseen sanajärjestykseen vaikuttavat argumenttirakenteen lisäksi muun muassa puhetilanne ja elementtien semanttiset ja kontekstuaaliset ominaisuudet. Sanajärjestyksen variaatio kuvataan generatiivisessa paradigmassa rakenteessa tapahtuvien siirtymien avulla, kuten alaluvussa 3.2 esittelin. Kuten transitiivilauseessa myös tunnekausatiivilauseessa sekä aiheuttaja että kokija voivat esiintyä lauseen teemapaikassa. Tunnekausatiivilauseen sanajärjestystä käsittelen alaluvussa 5.3 .

\subsection{Kongruenssi}

Suomessa sekä subjekti- että objektiargumentti voivat rakenteesta ja tulkinnasta riippuen esiintyä partitiivissa, ja toisaalta myös objekti voi tietyissä rakenteissa saada nominatiivisijan. Tunnekausatiivilauseen argumenttien sijamuodoista ei siis ole mahdollista mekaanisesti päätellä argumenttien roolia tai sijaintia rakenteessa. Kongruenssi sen sijaan paljastaa selvän eron näiden argumenttien välillä: suomessa finiittiverbi ei kongruoi objektiargumentin kanssa. ${ }^{12}$

Tunnekausatiiviverbi kongruoi nominatiivimuotoisen aiheuttajan kanssa myös aiheuttajan ollessa verbin jälkeisessä positiossa, minkä voi havaita vertailemalla esimerkkejä 30a-b. Sen sijaan partitiivisijaiset argumentit eivät suomessa aiheuta

12. Voidaan ajatella, että kongruenssi finiittiverbin kanssa sisältyy finiittilauseen subjektin määritelmään. Kongruenssi on kuitenkin yksi yhdistävä piirre transitiivilauseiden ja tunnekausatiivilauseiden subjektien välillä ja siksi kiinnostava vertailukohde. 
kongruenssia (esim. 3oc-d). Kongruenssin osalta aiheuttaja ja kokija siis käyttäytyvät kuten tyypillinen subjekti ja objekti.
(30) a. Ne lapset sälittävät Pekkaa.
b. Pekkaa säälittävät ne lapset.
c. Minä harmitan häntä.
d. ${ }^{*}$ Minua harmitan.

On kuitenkin syytä huomata, että puhekielisissä ilmaisuissa ei välttämättä ole lainkaan monikon 3. persoonan lukukongruenssia (esim. 31a-b). Myös 3. persoonan pronomini he näyttää sallivan marginaalisesti taivutuspiirteen pudottamisen puhekielisissä ilmaisuissa (esim. 32a-b).

(31) a. - - kyllä mua ne lapset säälittää... - - (Internet 9)

b. Mua niin säälittää ne lapset. (Internet 10)

(32) a. Minua he oksettaa. (Internet 11)

b. - - että he ärsyttää niin - - (Internet 12)

Monikkokongruenssin katoaminen 3. persoonassa (esim. 33a-b) näyttää olevan tunnekausatiiveilla samantyyppinen ilmiö kuin puhekielessä yleensäkin (VISK \$1280). Näissä tapauksissa voidaan olettaa, että verbi saa subjektilta kongruenssipiirteet, mutta ne jätetään puhekielessä lausumatta.

(33) a. - - he osti oman talon - - (Internet 13)

b. Meidän harjottelupaikassa ne lapset osti koulun kioskista nuudeleita ja söi niitä. (Internet 14)

Jos aiheuttajaan viitataan 1. tai 2. persoonan pronominilla, kongruenssi on pakollinen $(34 a-c)$.
（34） a. Minä säälitän sinua.
b. * Minä säälittää Pekkaa.
c. *Pekkaa säälittää minä.

Verbikongruenssi tukee siis ajatusta, että aiheuttaja on subjekti ja kokija on objekti. Kongruenssiin ja sen mekanismeihin ei ole mahdollisuutta paneutua tässä artikkelissa tämän tarkemmin.

\subsection{Anaforien sidonta}

Tarkastelen seuraavaksi refleksiivisen anaforan sidontaa. Kuten alaluvussa 3.3 esitin, anaforien sidontaan liittyvän ehdon A (condition A, Chomsky 1981) mukaan refleksiivinen anafora vaatii paikallisen k-komentavan korrelaatin. Suomessa sidonta- 
suhteet määräytyvät argumenttirakenteen perusteella, mikä tarkoittaa, että anaforan korrelaatti sijaitsee argumenttirakenteessa ylemmässä positiossa kuin anafora. Lisäksi sidontasuhteet säilyvät sanajärjestyksen varioidessa. Tarkastelen ensin refleksiivipronominia ja sen jälkeen refleksiivistä 3. persoonan possessiivisuffiksia. ${ }^{13}$

Esimerkit 35a-b osoittavat, että tunnekausatiivilauseen aiheuttaja voi sitoa kokijaa, joka on refleksiivipronomini. Anaforien sidontaehdon A mukaan aiheuttaja siis sijaitsee argumenttirakenteessa kokijan yläpuolella.

(35) a. - - silti hän inhotti itseään. (Internet 15)

b. Kyllä taas hävettää itseään - - (Internet 16)

Tunnekausatiivilauseet sallivat kuitenkin myös rakenteen, jossa partitiivimuotoinen kokija sitoo aiheuttajaa, joka on refleksiivipronomini. Tämä tilanne on esimerkiksi lauseissa 36-37 (VISK \$ 1448):

(36) Mikkoa harmitti / suretti itsensä. (Vilkuna 1989: 153)

（37） Häntä alkoi inhottaa itsensä. (Internet 17)

Vastaavat esimerkit ovat keskeisessä roolissa Nelsonin (2000) analyysissä, jossa kokija sijoitetaan aiheuttajan yläpuolelle. Nelson arvioi esimerkiksi lauseen $38 \mathrm{~b}$ huonommaksi kuin lauseen 38a. Näiden esimerkkien perusteella aiheuttaja sijaitsisi rakenteessa ylempänä kuin kokija.

\section{(38) (Nelson 2000)}

a. Itsensä näkeminen hävetti / pelotti häntä.

b. ??Pekka epäilytti / hävetti itseään.

Refleksiivipronomineihin liittyvät kieliopilliset testit eivät siis tuota ristiriidatonta tulosta. Kumpi sidontasuhteista on temaattisen argumenttirakenteen mukainen, ja kumpi edustaa poikkeustapausta? Seuraavaksi pyrin perustelemaan, miksi sidontasuhde aiheuttaja-kokija on ensisijainen verrattuna sidontasuhteeseen kokija-aiheuttaja.

Ensinnäkin Nelsonin esimerkkiin 38a liittyy ongelmia. Etenkään verbikantaisessa NP:ssä oleva refleksiivinen anafora ei aina vaadi paikallista korrelaattia. Sen sijaan kor-

13. Myös pronominien sidontaa on käytetty tunnekausatiivin syntaktisen analyysin perusteluna. Esimerkiksi Siro (1996 [1978]) käsittelee esimerkkiä (i) sidontasuhteesta, jossa pronominin edellä esiintyvä erisnimi ei voi sitoa pronominia. Vastaava ilmiö esiintyy myös transitiivilauseessa (ii). Pronominien sidontaan ei mennä tässä tarkemmin.

(i) (Siro 1996 [1978]: 184)

a. Ajatus siitä, että hänellä, olisi syöpä, vaivasi Jukkaa.

b. *Ajatus siitä, että Jukalla olisi syöpä, vaivasi häntä.

(ii) a. Ajatus siitä, että hänellä olisi syöpä, yllätti Jukan,.

b. *?Ajatus siitä, että Jukalla olisi syöpä, yllätti hänet. 
relaatti voi olla geneerinen, kuten NP itsensä näkeminen lauseissa 39a-b osoittaa. Yksin esiintyvä refleksiivipronomini ei olisi esimerkissä 38a kieliopillinen: *?Itsensä hävetti häntä.

(39) a. Sanotaan, että itsensä näkeminen unessa on harvinaista. (Internet 18)

b. Itsensä näkeminen ylivertaisena voi tarjota näennäisesti vakaan minäkuvan - - (Internet 19)

Lisäksi rakenteiden 40a-b vertailu osoittaa, että toisin kuin Nelson (200o) olettaa, sidontasuhde aiheuttaja-kokija on luontevampi kuin kokija-aiheuttaja. Mikä tärkeintä, edellinen sidontasuhde säilyy sanajärjestyksen varioidessa (esim. 40c), kun taas refleksiivipronomini ei tyypillisesti voi olla lauseenalkuinen aiheuttaja (esim. 4od).

(40) a. Pekka harmittaa itseään.

b. ?Pekkaa harmittaa itsensä.

c. Itseään harmittaa Pekka.

d. *Itsensä harmittaa Pekkaa.

Johtopäätöksenä voidaan todeta, että sidontasuhde, jossa aiheuttaja sitoo kokijana toimivaa refleksiivipronominia, vertautuu sidontasuhteeseen transitiivilauseen subjektin ja objektin välillä (ks. alalukua 3.3). Tämä havainto tukee kuvion 4 havainnollistamaa analyysiä, jossa aiheuttaja sijoittuu argumenttirakenteessa kokijan yläpuolelle. Päinvastaista sidontasuhdetta ei voida kuitenkaan kokonaan poissulkea. Artikkelisarjan toisessa osassa osoitan, että tunnekausatiivilauseiden lausemainen aiheuttaja-argumentti voi asettua tunnekausatiivilauseen komplementtipositioon, alemmas kuin kokija (Huhmarniemi tulossa 2019). Tämä analyysi avaa sen mahdollisuuden, että myös NP-muotoiset aiheuttajat voivat erityistapauksissa sijoittua komplementtiin. Nämä erityistapaukset voivat osaltaan selittää anaforien sidontaan liittyvää vaihtelua.

Refleksiivistä possessiivisuffiksia koskevat testit antavat samantyyppisen tuloksen kuin refleksiivipronominien tarkastelu. Korpusesimerkit 41a-b osoittavat, että aiheuttaja voi sitoa kokijan sisältämää refleksiivistä possessiivisuffiksia. Toisaalta myös päinvastaisia esimerkkejä tunnetaan (esim. 42).

(41) (Suomi24)

a. - - kunnanjohtaja ei miellytä työnantajaansa - -

b. Harva työpaikka, johon ei tarvi mitään koulutusta, miellyttää tekijäänsä.

(42) Voutilaista harmittaa ja säälittää kahden entisen seuransa, Kuusysin ja KuPS:n nykyinen alennustila. (VISK \$1448) 
Seuraavien esimerkkilauseiden vertailu osoittaa jälleen, että järjestys, jossa kokija sitoo aiheuttajaa (esim. 43b), on tunnusmerkkinen ${ }^{14}$ verrattuna lauseeseen, jossa aiheuttaja sitoo kokijaa (esim. 43a). Esitän, että lauseen (esim. 43b) tunnusmerkkisyys on seurausta siitä, että sidontasuhteen muodostaminen vaatii kokijan sijoittamista argumenttirakenteessa ylempään positioon kuin aiheuttaja, mikä on epätyypillistä, kun aiheuttaja on NP.

(43) a. Pekka surettaa oppilaitaan.

b. ?Pekkaa surettavat oppilaansa.

Seuraan näissä tapauksissa Huhmarniemen ja Bratticon (2015) analyysiä, jonka mukaan 3. persoonan possessiivisuffiksi voi tietyissä tilanteissa esiintyä ilman k-komentavaa korrelaattia. Tällöin korrelaatti haetaan kontekstista. Ilmiö on tyypillinen etenkin lauseissa, joissa refleksiivinen elementti esiintyy osana substantiivilauseketta kuten esimerkeissä 44-45.

(44) Kahden entisen seuransa, Kuusysin ja KuPS:n nykyinen alennustila aiheutti harmia Voutilaiselle.

(45) ?Pekan yllättivät entiset oppilaansa.

Johtopäätöksenä voidaan todeta, että anaforien sidontaa koskeva tarkastelu tukee analyysiä, jossa aiheuttaja sijaitsee argumenttirakenteessa ylempänä kuin kokija. Anaforien sidonta ei kuitenkaan anna ristiriidatonta tulosta. Palaan kysymykseen päätelmien yhteydessä luvussa 6 .

\subsection{Sanajärjestys}

Tässä luvussa tarkastelen tunnekausatiivilauseen sanajärjestystä. Esimerkiksi Nelson (2000, 2003) on esittänyt, että suomen tunnekausatiivilauseiden argumenttien sanajärjestys peilautuisi suoraan argumenttirakenteesta. Tästä näkemyksestä poiketen esitän, että tunnekausatiivilauseen sanajärjestys voi varioida melko vapaasti argumenttirakenteesta riippumatta. Rakenne asettaa kuitenkin muutamia rajoituksia sanajärjestyksen vaihtelulle. Esittelen aluksi sanajärjestykseen liittyviä testejä, jotka tukevat hypoteesia, jossa aiheuttaja sijoittuu kokijan yläpuolelle - vastaavasti kuin transitiivilauseen subjekti asettuu objektin yläpuolelle. Tämän jälkeen käsittelen tunnekausatiivilauseen sanajärjestystä ja siihen vaikuttavia tekijöitä. On merkillepantavaa, että Suomi24-korpusaineistossa partitiivimuotoinen kokija esiintyy verbin edellä jonkin verran useammin kuin nominatiivimuotoinen aiheuttaja. Tämä johtuu nähdäkseni

14. Tarkoitan tunnusmerkkisyydellä sanajärjestyksen yhteydessä Ison suomen kieliopin määritelmää, jonka mukaan "[t]unnusmerkkinen sanajärjestys, esim. Olen minä täällä ennenkin käynyt, on suppeakäyttöisempi ja tehtävältään rajallisempi kuin lausetyypin tavallinen järjestys (Minä olen käynyt täällä ennenkin)." (VISK, määritelmät, s.v. tunnusmerkkisyys.) 
siitä, että tunnekausatiivilauseen sanajärjestykseen vaikuttavat vahvasti puhetilanne ja elementtien informaatiosisältö.

Nelson (2000, 2003) esittää, että tunnekausatiivilauseeseen liittyy kaksi erilaista argumenttirakennetta. Hän seuraa Pesetskyn (1995) ehdotusta, jonka mukaan temaattiset roolit muodostavat hierarkian aiheuttaja $>$ kokija $>$ kohde. Nelsonin mukaan nominatiivimuotoisen argumentin temaattinen rooli riippuu sen sijainnista rakenteessa. Kokijan yläpuolelle siirtynyt nominatiivimuotoinen argumentti tulkitaan aiheuttajaksi ja kokijan alapuolella oleva argumentti kohteeksi. Nelson esittää myös, että temaattinen rakenne korreloi sanajärjestyksen kanssa kuten seuraavissa esimerkeissä:

(46) Nelson (2000)

a. Vaimonsa näkeminen miellytti häntä. (aiheuttaja, kokija)

b. Häntä miellytti vaimonsa näkeminen. (kokija, kohde)

Näkemykseni eroaa tässä Nelsonin käsityksestä, ja väitän, että molemmat variantit (esim. 46a-b) sallivat kummankin tulkinnan. Vertailen transitiivilausetta ja tunnekausatiivilausetta toisiinsa ja osoitan, että tunnekausatiivilauseen aiheuttaja käyttäytyy valituissa konteksteissa samalla tavoin kuin transitiivilauseen subjekti. Tämä viittaa siihen, että myös argumenttien järjestys rakenteessa on sama: subjekti/aiheuttaja on ylempänä kuin objekti/kokija.

Suomen finiittilauseessa puheenaihe sijaitsee tyypillisesti lauseen teemapaikassa ja loppukenttä toimii lauseen reemana. Subjekti on lauseen oletusarvoinen teema (VISK \$1372) kuten esimerkissä 47a. Loppukentässä oleva subjekti voi olla joko tunnusmerkkinen (esim. 47b) tai neutraali (esim. 47c). Tulkintaan vaikuttavat etenkin lauseen tyyppi ja subjektin ominaisuudet (VISK $\$ 1374-1375$ ).

(47) a. Johtaja tekee päätöksen.

b. Päätöksen tekee johtaja.

c. Minua pisti ampiainen.

Tunnekausatiivilauseen kokija sijaitsee oletusarvoisesti teemapaikassa lauseissa, jotka eivät sisällä aiheuttajaa, kuten esimerkissä 48a. Aiheuttaja sijoittuu usein verbin jälkeen (VISK \$ 905), mutta se voi sijaita myös verbin edellä (esim. 48b). Vaikuttaa siltä, että myös verbinjälkeinen aiheuttaja voi olla joko tunnusmerkkinen (esim. 48c) tai neutraali (esim. 48d).

(48) a. Merjaa harmittaa.

b. Johtaja surettaa Merjaa.

c. Merjaa surettaa johtaja.

d. Minua surettaa ampiainen.

Lauseen elementtien informaatiosisältöä on mahdollista tarkastella kysymys-vastausparien avulla. Konstituentti, joka vastauksessa korvaa kysymyssanan, on uutta infor- 
maatiota. Esimerkki 49a osoittaa, että uutta informaatiota sisältävä transitiivilauseen subjekti voi sijaita teemapaikassa tai loppukentässä osana reemaa; esikentän jätän tässä tarkastelun ulkopuolelle. Esimerkin 49b perusteella uutta informaatiota sisältävä objektiargumentti ei vastauksessa voi sijaita teemapaikassa. Jos subjekti sijaitsee loppukentässä jo kysymyksessä (esim. 49c), se voi sijaita loppukentässä myös vastauksessa.

(49) a. Kuka etsii Merjaa?

- Lapsi etsii Merjaa. / - Merjaa etsii lapsi.

b. Ketä lapsi etsii?

- Lapsi etsii Merjaa. / \# - Merjaa etsii lapsi.

c. Ketä etsii lapsi?

- Lapsi etsii Merjaa. / - Merjaa etsii lapsi.

Vastaava testi tunnekausatiivilauseelle osoittaa, että nominatiivimuotoinen aiheuttaja voi toimia vastauksena kysymykseen sekä teemapaikassa että osana reemaa (esim. 50a). Sen sijaan uutta informaatiota sisältävä partitiivimuotoinen kokija ei voi esiintyä teemapaikassa (esim. 5ob). Samoin kuin edellä, subjekti voi sijaita loppukentässä vastauksessa, jos se sijaitsee loppukentässä myös kysymyksessä (esim. 50c).

(50) a. Kuka surettaa Merjaa?

- Lapsi surettaa Merjaa. / - Merjaa surettaa lapsi.

b. Ketä lapsi surettaa?

- Lapsi surettaa Merjaa. / \# - Merjaa surettaa lapsi.

c. Ketä surettaa lapsi?

- Lapsi surettaa Merjaa. / - Merjaa surettaa lapsi.

Kysymys-vastaus-pareissa 49a-b ja 50a-b tunnekausatiivin aiheuttaja ja kokija käyttäytyvät lauseen informaatiorakenteen kannalta samalla tavoin kuin transitiivilauseen subjekti ja objekti. Tämä antaa aiheen olettaa, että samoin kuin perussubjekti tunnekausatiivin nominatiivimuotoinen aiheuttaja toimii lauseen rakenteen kannalta oletusarvoisena teemana.

Toinen sanajärjestysesimerkki koskee pronominien sijaintia. Mikäli tunnekausatiivilauseen aiheuttaja on pronomini, se on verbin jäljessä tunnusmerkkinen (esim. 51a-b; ks. myös VISK $\$ 905)$. Kokijalla ei ole vastaavaa rajoitusta (esim. 51C).

(51) a. Hän suretti Merjaa.

b. Merjaa suretti hän.

c. Merja suretti häntä.

Ilmiö on sama kuin transitiivilauseen subjektin ja objektin välillä. Transitiiviverbin jäljessä esiintyvä pronominaalinen subjekti on tunnusmerkkinen (esim. 52a-b). Objektina toimivan pronominin sijoittaminen verbin jälkeen taas on vaivatonta (esim. 52c). 
(52) a. Hän katseli Merjaa.

b. Merjaa katseli hän.

c. Merja katseli häntä. ${ }^{15}$

Tunnekausatiiveilla on siis samanlainen pronominaalisen objektin sijaintiin liittyvä rajoitus kuin transitiivilauseella. Tämä viittaa siihen, että tunnekausatiivilauseen aiheuttajalla on informaatiorakenteen kannalta samantyyppinen asema kuin transitiivilauseen subjektilla. Alaluvussa 3.2 esitin, että elementin siirtymä teemapaikkaan noudattaa läheisyysperiaatetta: mikäli puhetilanne ei anna muuhun aihetta, teemapaikkaan siirretään lähin sopiva elementti. Tämän perusteella aiheuttaja olisi lähin elementti myös tunnekausatiivilauseissa. Kuvio 5 esittää ehdotetun rakenteen sekä aiheuttajan ja kokijan siirtymät lauseen teemapaikkaan.
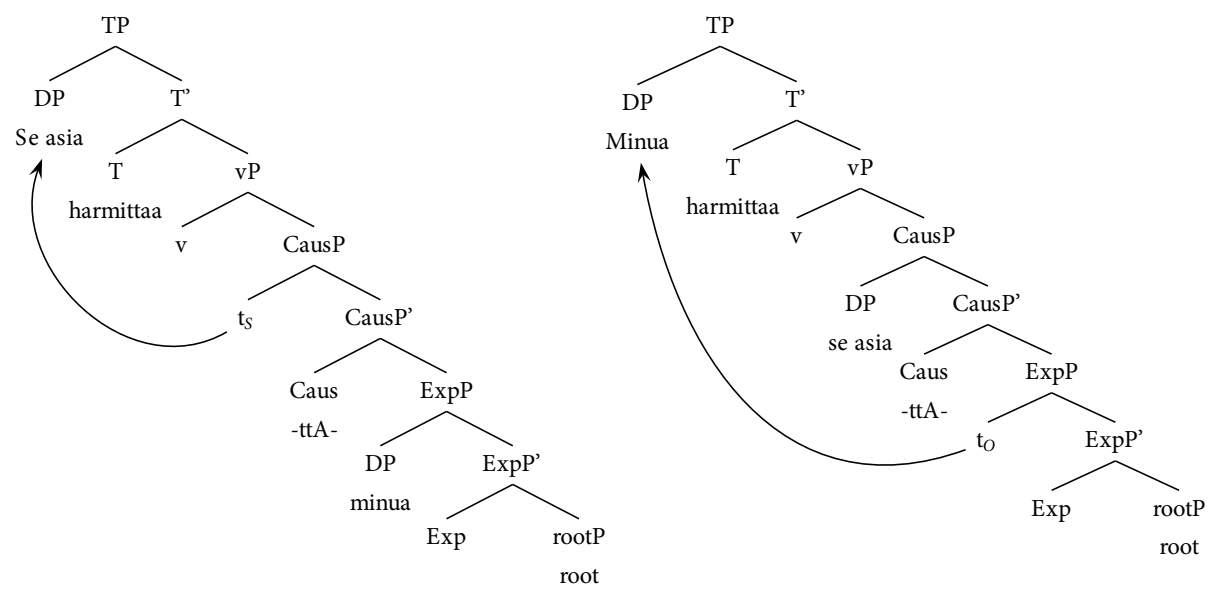

Kuvio 5.

Aiheuttajan ja kokijan siirtymät lauseen teemapaikkaan.

15. Artikkelin arvioija toi ilmi mahdollisuuden, että esimerkkien 52b-c kaltainen kontrasti liittyisi verbinjälkeisen pronominin pituuteen. Siirtymää suomen teemapaikkaan voidaan verrata skandinaavisten kielten object shift -ilmiöön. Esimerkiksi lauseessa Varför köper Johan den inte? objekti on siirtynyt kieltosanan yli verbin noustessa ylempään positioon. Josefsson (2010) esittää, että pidemmät pronominit, kuten honom ja henne, pysyvät useammin paikallaan kuin esimerkiksi yksitavuinen pronomini den. Tällainen periaate voisi selittää, miksi lause i-b olisi tunnusmerkkinen verrattuna lauseeseen i-a. Pronominin pituuteen perustuvan kontrastin pitäisi kuitenkin esiintyä myös lausepareissa ii ja iii, mutta vastaavaa eroa lauseiden välillä ei ole mahdollista havaita. Näyttää siis siltä, että pronominin pituudella ei ole suoraa vaikutusta lauseen teemapaikkaan kohdistuviin siirtymiin.

(i) a. Merja rakastaa häntä.

b. Merjaa rakastaa hän.

(ii) a. Merjaa rakastan minä.

b. Merjaa rakastatte te.

(iii) a. Merjaa rakastat sinä.

b. Merjaa rakastat sä. 
On kuitenkin syytä huomata, että kokijan siirtäminen lauseen teemapaikkaan voi silti olla kielessä yleisempää kuin aiheuttajan siirtymä. Siirtymään vaikuttavat kieliopillisten seikkojen lisäksi puhetilanne ja lauseen elementtien informaatiosisältö.

Siirtymän yleisyyden selvittämiseksi tarkastelin tunnekausatiivilauseiden sanajärjestystä Suomi24-korpusaineistossa (Suomi24; Lagus, Panzar, Ruckenstein \& Ylisiurua 2016). Korpus sisältää noin 2,7 miljardia sanetta Suomi24-keskustelufoorumilta. ${ }^{16}$ Etsin tunnekausatiivilauseiden ominaisuuksia CQP-hakulausekkeilla (Corpus Query Protocol) Korp-käyttöliittymän avulla. Valitsin korpuksesta 36 tunnekausatiiviverbin esiintymät indikatiivissa, joita oli yhteensä noin 484 ooo. Aineisto ei sisällä verbejä, jotka esiintyvät myös perussubjektillisissa rakenteissa. Niin kutsuttuja tunneverbejä valitsin aineistoon 18 (yhteensä 421 ooo esiintymää), tuntemusverbejä samoin 18 (yhteensä 63 ooo esiintymää). ${ }^{17}$ Verbien valinnassa käytin Ison suomen kieliopin jaottelua (VISK $₫ 465,467$ ), jonka mukaan tunneverbit voidaan liittää useammin mentaalisen tilan ja tuntemusverbit ruumiillisen tunteen ilmaisemiseen. Aineistoon poimimani verbit ovat seuraavat:

Tunneverbit (18 kappaletta, 421 ooo esiintymää indikatiivissa):

harmittaa, hävettää, hirvittää, ihmetyttää, inhottaa, kaduttaa, kiukuttaa, korveta, nolottaa, pänniä, risoa, säälittää, sapettaa, surettaa, tympiä, ujostuttaa, vituttaa, ällöttää

Tuntemusverbit (18 kappaletta, 68 ooo esiintymää indikatiivissa): aivastuttaa, heikottaa, hikoiluttaa, hiukoa, huimata, janottaa, jomottaa, kihelmöidä, kirvellä, kuumottaa, kuvottaa, närästää, oksettaa, puistattaa, pyörryttää, vihloa, viluttaa, yskittää

Sanajärjestyksen variaation tarkastelua varten etsin korpuksesta tunnekausatiivilauseita, joissa aiheuttaja ja kokija ovat molemmat nominilausekkeita. Järjestys aiheuttaja-verbi-kokija (AVK) esiintyy keskimäärin 3 prosentissa kaikista tunnekausatiivilauseista ja KVA noin 6 prosentissa. Tarkempaan analyysiin valitsin lauseita, joissa jompikumpi tai molemmat argumentit ovat läsnä. Kaikista tunnekausatiivien esiintymistä noin $19 \%$ on tapauksia, joissa aiheuttaja-NP sijaitsee ennen tunnekausatiiviverbiä ja kokija sijoittuu joko verbin jälkeen tai puuttuu lauseesta kokonaan. Kokija puolestaan esiintyy verbiä ennen noin 22 prosentissa tapauksista. Noin 70 \% korpuksen tunnekausatiivilauseista ei sisällä kokija-argumenttia lainkaan. Kuviossa 6 sivulla 394 on esitetty ote verbin edellä olevan argumentin jakaumista. Kuviosta voi huomata, että sanajärjestykseen liittyy paljon verbikohtaista vaihtelua. Kuviossa verbit on järjestetty sen mukaan, miten vahvasti ne noudattavat järjestystä kokija-verbi. Sen tavoitteena on antaa yleiskuva ilmiöstä, ja tulokset ovatkin vasta

16. Korpukseen kuuluvat kaikki Suomi24-keskustelufoorumin tekstit aikaväliltä 1.1.2001-24.9.2016. Korpus sisältää morfosyntaktisen analyysin, jonka on tuottanut Kielipankki, FIN-CLARIN. Tekstiaineistoon voi tehdä hakuja Korp-käyttöliittymän kautta (korp.csc.fi).

17. Vaihtoehtoinen perussubjektillinen rakenne on ainakin tunneverbeillä miellyttää, hermostuttaa, jännittää, ahdistaa, kammottaa, huvittaa ja tuntemus verbeillä heitättää, nukuttaa, palella, aivastuttaa, kutista ja pissattaa. Eräänlaisiksi rajatapauksiksi voidaan tulkita ainakin tunneverbit inhottaa, ujostuttaa, hirvittää, ihmetyttää ja tuntemusverbit oksettaa ja kuvottaa. Perussubjektillisella variantilla on näiden verbien osalta kuitenkin vain vähäinen merkitys tuloksiin. 


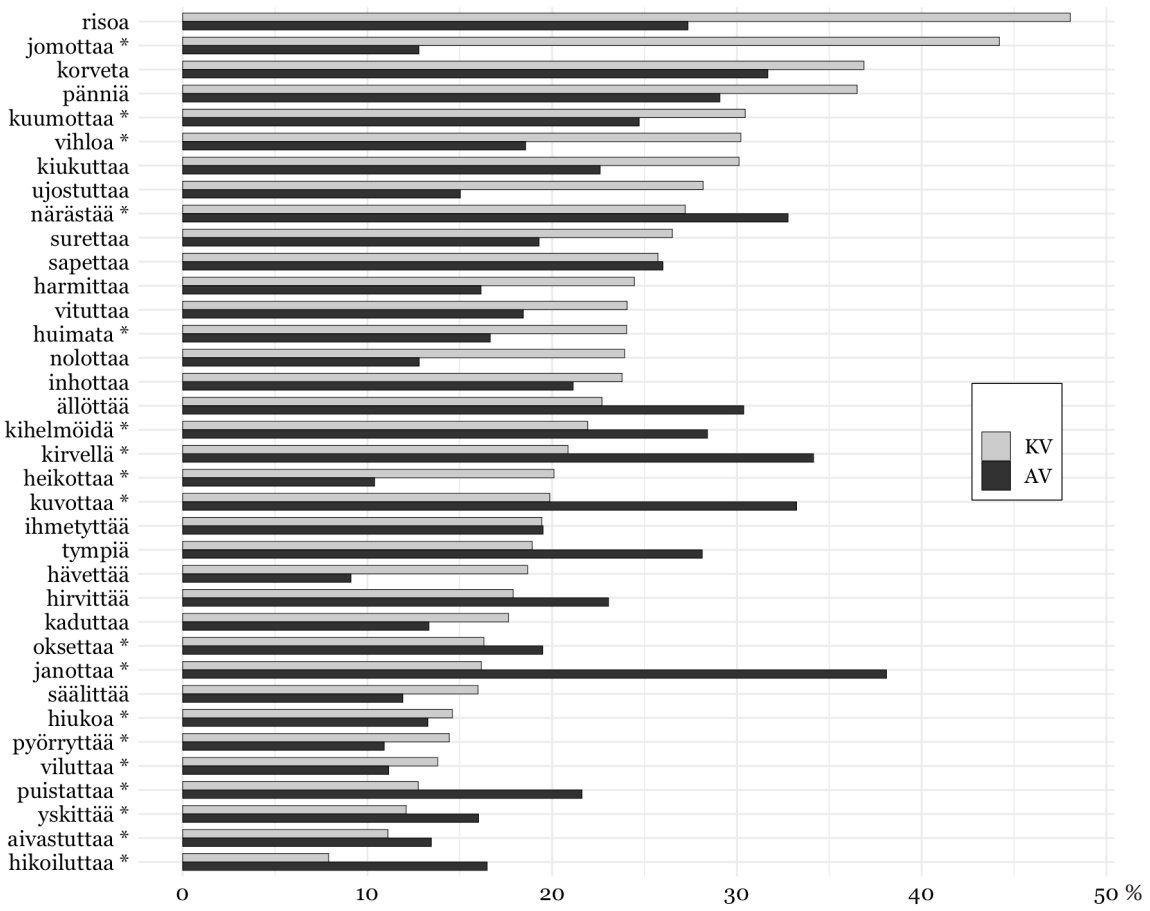

Kuvio 6.

Kokija- ja aiheuttaja-argumenttien yleisyydet verbin edellä suhteessa kaikkiin verbin esiintymiin indikatiivissa. KV = kokija esiintyy finiittiverbin edellä ja aiheuttaja esiintyy lauseessa joko verbin jäljessä tai ei lainkaan. AV = aiheuttaja esiintyy finiittiverbin edellä ja kokija joko verbin jäljessä tai ei lauseessa lainkaan. Tuntemusverbit on merkitty tähdellä (*).

suuntaa antavia. Verbikohtaisen vaihtelun ja siihen vaikuttavien tekijöiden selvittäminen vaatii tarkempaa tutkimusta.

Korpusaineiston perusteella kokija siis esiintyy jonkin verran useammin finiittiverbin edellä kuin aiheuttaja. Iso suomen kielioppi asettaakin kokijan tunnekausatiivilauseen oletusarvoiseksi teemaksi. Samoin Siiroinen (2005) on kuvannut tunnekausatiivia konstruktiolla, jossa kokija on verbin edellä. On kuitenkin mielenkiintoista, että argumenttien väliset erot eivät aineistossa ole suurempia. Yksi tulosta selittävä tekijä on ilman kokijaa esiintyvien tunnekausatiivilauseiden, kuten harmittaa, yleisyys. Ilman kokijaa esiintyvät tunnekausatiivit ovat impersonaalisia ja viittaavat yleensä kirjoittajaan.

Kokijan suhteellinen yleisyys teemapaikassa voidaan nähdä ongelmaksi tämän artikkelin pääargumentille, jonka mukaan aiheuttaja-NP olisi lauseessa ylempänä ja tämän takia rakenteen kannalta oletusarvoinen teema. Oletan, että ilmiötä selittää osaltaan se, että valtaosa tunnekausatiivilauseista on subjektiivisia ilmaisuja, joissa kokija on henkilöviitteinen ja viittaa joko puhujaan tai johonkin puhetilanteen osallistujista (ks. myös Siiroinen 2001, 2002). Vahvasti kontekstiin tukeutuvat pronominit asettuvat useammin verbin edelle kuin muut NP:t. Esimerkiksi pronominaalinen subjekti esiintyy verbin edellä useammin kuin NP-subjekti (Helasvuo 2001: 79-81). 
Suomi24-aineistosta voidaan löytää tukea tälle näkemykselle. Kokija on pronominaalinen tai sisältää demonstratiivipronominin noin 50 prosentissa AVK-lauseista ja 82 prosentissa KVA-lauseista. Aiheuttaja puolestaan on pronominaalinen tai sisältää demonstratiivipronominin keskimäärin 14 prosentissa KVA-lauseista ja 44 prosentissa AVK-lauseista. Aineiston perusteella voidaan siis todeta, että KVA-lauseissa kokija on usein pronominaalinen. Nämä tulokset ovat kuitenkin vasta alustavia.

\section{Päätelmät}

Suomen tunnekausatiivilause tarjoaa monipuolisen tutkimuskohteen kielen rakenteen tarkasteluun. Kausatiivisuus ja kausatiivimorfeemin vaikutus lauseen tulkintaan muodostaa oman tutkimuskokonaisuutensa, jota tässä artikkelissa on vain lyhyesti sivuttu. Tarkastelun kohteena on ollut tunnekausatiivilauseen argumenttien hierarkkinen asema rakenteessa.

Monissa aiemmissa syntaktisissa analyyseissä on päädytty jäsentämään tunnekausatiivilauseen argumentit hierarkkisesti siten, että partitiivimuotoinen kokija sijoittuu ylemmäs kuin nominatiivimuotoinen aiheuttaja; myös kokijan yleisyys teemapaikassa on ohjannut tähän tulkintaan. Tässä artikkelissa olen pyrkinyt osoittamaan, että aineiston kieliopillinen analyysi ei tue tätä näkemystä. Kun tarkastellaan kongruenssia, anaforien sidontaa ja sanajärjestystä, voidaan päätellä, että tunnekausatiivilause muodostetaan argumenttirakenteesta, jossa aiheuttaja sijoitetaan kokijan yläpuolelle.

Tulokseen liittyy kuitenkin epätarkkuutta, joka johtuu osaksi tunnekausatiivilauseelle tyypillisestä sanajärjestyksen vaihtelusta. Korpusaineiston perusteella kokijaobjekti on jopa yleisempi lauseen teemapaikassa kuin aiheuttajasubjekti. Toisaalta myös anaforien sidontaan liittyvät testit antavat osittain ristiriitaisia tai epäselviä tuloksia.

On mahdollista löytää tekijöitä, jotka vaikuttavat sanajärjestyksen variaation taustalla. Ensinnäkin nyt esitetyssä analyysissä tunnekausatiivin molemmat argumentit sijaitsevat verbilausekkeen sisällä, ja tämä voi osaltaan vaikuttaa siihen, että sanajärjestykseen ja anaforien sidontaan liittyy enemmän vaihtelua kuin on esimerkiksi ulkoisen subjektin ja objektin välillä. Kokija-alkuisten tunnekausatiivilauseiden esiintymisen yleisyyttä korpusaineistossa selittää myös henkilöviitteisten pronominien yleisyys kokijaobjekteina. Puhetilanteen osallistujiin viittaavat pronominit hakeutuvat teemapaikkaan yleisemmin kuin esimerkiksi abstraktit substantiivit.

Epäselviä tuloksia voisi myös selittää kielessä mahdollisesti meneillään oleva argumenttirakenteen muutos, jossa partitiivimuotoinen aiheuttaja on ottamassa subjektin aseman (Siiroinen 2005). Kolmas vaihtoehto on, että suomen tunnekausatiivilauseet voidaan muodostaa kahdesta erilaisesta rakenteesta, joista toinen on kuitenkin yleisempi kuin toinen. Kahden vaihtoehtoisen rakenteen olemassaolo nostetaan esiin artikkelisarjan toisessa osassa (Huhmarniemi tulossa 2019) Siinä esitän, että lausemainen aiheuttaja asettuu rakenteessa eri positioon kuin tässä artikkelissa tarkastellut aiheuttaja-NP:t. 
Lopuksi voidaan todeta, että tunnekausatiivilauseen rakenteeseen liittyy edelleen useita avoimia kysymyksiä. Tunnekausatiivilauseet muodostavat mielenkiintoisen tutkimuskohteen, johon viimeaikaiset Internet-keskusteluaineistot avaavat uusia näkymiä. Toisaalta tunnekausatiivilauseet tarjoavat monipuolista aineistoa esimerkiksi sanajärjestykseen, subjektin ja objektin asemaan, sijakiinnitykseen ja anaforien sidontaan liittyvien lainalaisuuksien tutkimiseksi.

\section{Lähteet}

\section{Aineistolähteet}

Internet 1 = https://jpkoskinen.wordpress.com/2017/o8/o8/miksi-vr-ei-kuuntele-asiakkaitaan/ (1.10.2019).

Internet 2 = https://alzheimerinfo.fi/alzheimerin-taudista-kysyttya/taudin-nopea-eteneminenihmetyttaa/ (1.10.2019).

Internet $3=$ https://www.vauva.fi/keskustelu/2863215/jahas-synttarikutsu-sukulaislapsen-synttareille-ja-tilinumero-mukana (1.10.2019).

Internet $4=\mathrm{http}: / /$ leenanhuokaukset.blogspot.com/2011/07/ (1.10.2019).

Internet $5=$ https://keskustelu.tekniikanmaailma.fi/discussion/234025/rattijuoppous-vaehentynyt (1.10.2019).

Internet $6=\mathrm{http}: / / \mathrm{www} \cdot$ arvostan.net/perussetti/i-htm/ (1.10.2019).

Internet $7=$ https://keskustelu.suomi24.fi/t/14740603/mietin-saastamisen--vaihtoehtoja (1.10.2019).

Internet $8=$ http://annelinajatuksia.blogspot.com/2015/o3/salakuvausta-murhemielella.html (1.10.2019).

Internet $9=$ https://keskustelu.suomi24.fi/t/12162318/tuija-lampela-myy-kamppaa- (1.10.2019). Internet $10=$ https://www.etlehti.fi/blogit/maan-korven-kulkijoita/raivoa-ja-rakkautta (1.10.2019).

Internet $11=$ https://keskustelu.suomi24.fi/t/1638664/ihastuneen-ahdistelua (1.10.2019).

Internet $12=$ https://keskustelu.suomi24.fi/t/5319404/pikkuveli-arsyttaa (1.10.2019).

Internet 13 = https://www.vauva.fi/keskustelu/2518437/suomen_ihanimmat_haat_avalla_nyt (1.10.2019).

Internet $14=$ http://happyinhollandjonna.blogspot.com/ (1.10.2019).

Internet $15=$ http://bemysweet.palstani.com/t645-wasting-my-time (1.10.2019).

Internet $16=\mathrm{http}: / /$ kivileijonia.blogspot.com/2019/o6/tiantan-tanlines.html (1.10.2019).

Internet $17=$ https: $/ /$ www.finfanfun.fi/index.php?topic=31424.0 (1.10.2019).

Internet $18=$ https://www.mtvuutiset.fi/artikkeli/miksi-moni-nakee-painajaisia-jahdatuksitulemisesta-asiantuntija-kertoo-voiko-unia-tulkita-ja-mita-ne-paljastavat/7279768 (1.10.2019).

Internet $19=$ https://www.vaestoliitto.fi/parisuhde/tietoa_parisuhteesta/mielenterveys-japarisuhde/miten-irtaudut-ja-selviydyt-suht/narsistin-ihmissuhteet-ovat-hair/ (1.10.2019).

Kirstilä, Pentti 2002: Hanhivaara ja mies joka murhasi vaimonsa. Helsinki: WSOY.

SUомI24 = Aller Media Oy 2014: Suomi 24 -korpus (2016H2) [tekstikorpus]. Kielipankki. http://urn.fi/urn:nbn:fi:lb-2017021506. 
Kirjallisuuslähteet

Alexiadou, Artemis - Anagnostopoulou, Elena - Schäfer, Florian 2006: The properties of anticausatives cross-linguistically. - Mara Frascarelli (toim.), Phases of interpretation s. 187-212. Berlin: Mouton de Gruyter.

BAKER, MARK 1985: The mirror principle and morphosyntactic explanation. - Linguistic Inquiry 16 s. 373-415.

Burzio, Luigi 1986: Italian syntax. Dordrecht: Reidel.

Cathcart, Mary Ellen - Vainikka, Anne 2019: Re-analysis of causative morphology in Finnish. Käsikirjoitus, viitattu 9.8.2019. University of Delaware.

Chомsкy, NoAm 1981: Lectures in government and binding. The Pisa lectures. Dordrecht: Foris.

1995: The Minimalist program. Cambridge, MA: MIT Press.

Hakulinen, Auli - Karlsson Fred 1979: Nykysuomen lauseoppia. Helsinki: Suomalaisen Kirjallisuuden Seura.

Halle, Morris - Marantz, Alec 1993: Distributed morphology and the pieces of inflection. - Ken Hale \& Samuel Jay Keyser (toim.), View from Building 20. Essays in linguistics in honor of Sylvain Bromnerger s. 111-176. Cambridge, MA: MIT Press.

HARLEY, Heidi 2013: External arguments and the mirror principle. On the distinctness of voice and v. - Lingua 125 s. 34-57.

Helasvuo, MARJA-LiIs a 2001: Syntax in the making. The emergence of syntactic units in Finnish conversation. Amsterdam: John Benjamins.

Holmberg, Anders - Nikanne, Urpo 2002: Expletives, subjects, and topics in Finnish. - Peter Svenonius (toim.), Subjects, expletives, and the EPP s. 71-106. Oxford: Oxford University Press.

Huhmarniemi, SAARA 2012: Finnish A'-movement. Edges and islands. Institute of Behavioural Sciences, Studies in Cognitive Science 2. University of Helsinki: Helsinki. http://urn.fi/ URN:ISBN:978-952-10-7712-8.

2019: The movement to SpecFinP in Finnish. - Acta Linguistica Academica 66 s. 85-113.

_ (tulossa) 2019: Tunnekausatiivilauseen argumenttirakenne II. Lausemainen aiheuttaja. Virittäjä 123.

Huhmarniemi, SaAra - Brattico, Pauli 2015: The Finnish possessive suffix. - FinnoUgric Languages and Linguistics 4 s. 2-41. http://full.btk.ppke.hu/index.php/FULL/article/ view/31.

JosefsSon, GUnlög 2010: Object shift and optionality. An intricate interplay between syntax, prosody and information structure. - Working papers in Scandinavian syntax 86 s. 1-24. Lund: Centre for Languages and Literature, Lund University.

Kratzer, Angelika 1996: Severing the external argument from its verb. - Johan Rooryck \& Laurie Zaring (toim.), Phrase structure and the lexicon s. 109-137. New York: Springer.

Kupula, Miкко 2010: Causers as derived subjects. An unaccusative view from Finnish. - Working papers in Scandinavian Syntax 86 s. 199-219. Lund: Centre for Languages and Literature, Lund University.

Lagus, Krista - Panzar, Mika - Ruckenstein, Minna - Ylisiurua, Marjoriikka 2016: SUOMI24. Muodonantoa aineistolle. Kuluttajatutkimuskeskus, Valtiotieteellisen tiedekunnan julkaisuja 10. https://researchportal.helsinki.fi/fi/publications/suomi24-muodonantoa-aineistolle.

Manninen, Satu - Nelson, Diane 2004: What is a passive? The case of Finnish. - Studia 
Linguistica 58 s. 212-251.

Marantz, Alec 1997: No escape from syntax. Don't try morphological analysis in the privacy of your own lexicon. - Alexis Dimitriadis, Laura Siegel, Clarissa Surek Clark \& Alexander Williams (toim.), Proceedings of the 21st annual Penn linguistics colloquium. Penn Working Papers in Linguistics 4 s. 201-225. Philadelphia: University of Pennsylvania.

Nelson, Diane 2000: Linking causatives and experiencers. - Leeds working papers in linguistics 8 s. 149-177.

- 2003: Case and event structure in Finnish psych predicates. - Ellen Brandner \& Heike Zinsmeister (toim.), New perspectives on case theory s. 191-221. Stanford: CSLI Publications.

Pesetsky, David 1995: Zero syntax. Experiencers and cascades. Cambridge, MA: MIT Press. Pylkkënen, LiınA 1999a: Causation and external arguments. - Liina Pylkkänen, Angeliek van Hout \& Heidi Harley (toim.), Papers from the second Penn/MIT roundtable on argument structure and the lexicon. MITWPL 35 s. 161-183 Cambridge, MA: MITWPL.

1999b: On stativity and causation. - Carol Tenny \& James Pustejovsky (toim.), Events as grammatical objects s. 417-444. Stanford: CSLI.

2002: Introducing arguments. Cambridge, MA: MIT, Department of Linguistics and Philosophy.

PÖRn, Michaela 2001: Valinnaisesti ja pakollisesti kausatiiviset tunnekausatiivit ja niiden argumenttirakenne. - Puhe ja kieli 2 s. 115-128.

SiIroinen, MARI 2001: Kuka pelkää, ketä pelottaa. Nykysuomen tunneverbien kielioppia ja semantiikkaa. Helsinki: Suomalaisen Kirjallisuuden Seura.

— 2002: "Jopas kortittaa”. Nykysuomen tunnekausatiivilauseen alkuperää jäljittämässä Ilona Herlin, Jyrki Kalliokoski, Lari Kotilainen \& Tiina Onikki-Rantajääskö (toim.), Äidinkielen merkitykset s. 210-227. Helsinki: Suomalaisen Kirjallisuuden Seura.

- 2005: An overview of mental verbs in Finnish. - M. M. Jocelyne Fernandez-Vest (toim.), Les langues ouraliennes aujourd'hui. The uralic languages today s. 316-326. Paris: Champion.

Siro, PaAvo [1978] 1996: Kausatiivien kielioppia. - Pentti Leino (toim.), Lauseopin periaatteita. Kaksitoista artikkelia. Helsinki: Helsingin yliopiston suomen kielen laitos.

Trosterud, Trond 1993: Anaphors and binding domains in Finnish. - Anders Holmberg \& Urpo Nikanne (toim.), Case and other functional categories in Finnish syntax s. 225-243. New York: Mouton de Gruyter.

VAINIKKA, Anne 1989: Deriving syntactic representations in Finnish. University of Massachusetts Amherst.

VILKUnA, MARIA 1989: Free word order in Finnish. Its syntax and discourse functions. Helsinki: Suomalaisen Kirjallisuuden Seura.

2002: Tunneverbit askarruttavat - Virittäjä 106 s. 119-124.

VISK = Hakulinen, Auli - Vilkuna, Maria - Korhonen, Rittta - Koivisto, Vesa - Heinonen, TARja Rittta - Alho, Irja 2004: Iso suomen kielioppi. Helsinki: Suomalaisen Kirjallisuuden Seura. Verkkoversio. http://scripta.kotus.fi/visk URN:ISBN:978-952-5446-35-7 (20.2.2018). 


\section{The argument structure of the Finnish experiencer construction I: An NP causer}

This article investigates the Finnish experiencer construction, which involves a psychological predicate and two optional arguments: the nominative causer and the partitive experiencer. The argument structure of the Finnish experiencer construction has remained an open question in syntactic theories. In this paper, several grammatical tests concerning congruence, binding and word order are applied in the framework of generative syntax. They suggest that when the nominative causer is an NP, it typically occupies a higher position in the argument structure than the partitive experiencer. This result is evaluated against data from the Suomi24 corpus, which reveals that the partitive experiencer occurs preverbally more frequently than the nominative causer. The article asserts that the word order of the Finnish experiencer construction reflects contextual factors and discourse features of the arguments.

This article is the first in a series of two. The second article investigates experiencer constructions with an embedded clause as a causer argument. 


\section{Tunnekausatiivilauseen argumenttirakenne I: NP aiheuttajana}

Tunnekausatiivilauseet luokitellaan usein omaksi lausetyypikseen, johon kuuluu tunnetta tai tuntemusta ilmaiseva verbi (tunnekausatiivi), partitiivisijainen kokija ja nominatiivimuotoinen aiheuttaja. Tunnekausatiivilauseen aiheuttaja- ja kokijaargumenttien asemaa syntaktisessa rakenteessa on pidetty avoimena kysymyksenä ja rakenteen on arvioitu jopa olevan muutoksessa. Tässä artikkelissa käydään generatiivisen kieliopin kehyksessä läpi argumenttirakenteeseen liittyviä kieliopillisia testejä, jotka koskevat esimerkiksi kongruenssia, anaforien sidontaa ja sanajärjestystä. Testien perusteella voidaan havaita, että kun tunnekausatiivilauseen aiheuttaja on NP, se sijaitsee tyypillisesti argumenttirakenteessa ylempänä kuin partitiivimuotoinen kokija. Tätä tulosta verrataan Suomi24-korpusaineistosta tehtyihin havaintoihin, joiden perusteella kokija esiintyy useammin verbin edellä kuin aiheuttaja. Tunnekausatiivilauseen sanajärjestyksen vaihtelun katsotaan olevan sidoksissa puhetilanteeseen ja argumenttien ominaisuuksiin.

Tämä artikkeli on osa kahden artikkelin sarjaa. Sarjan toisessa osassa tarkastellaan lausemaisten aiheuttajien asemaa tunnekausatiivilauseen argumenttirakenteessa.

Kirjoittajan yhteystiedot (address):

etunimi.sukunimi@helsinki.fi

Kirjoittaja on kognitiotieteen post doc -tutkija Helsingin yliopistossa. 